\title{
Millennials' Contribution in Disaster Risk Reduction: Case Study of Tidal Flooding in Semarang
}

\author{
Theresia Octastefani ${ }^{1}$, Muhammad Rum ${ }^{2}$ \\ ${ }^{1}$ Department of Politics and Government, Faculty of Social and Political Sciences; and \\ Center for Southeast Asian Social Studies, Universitas Gadjah Mada \\ (email: theresiaoctastefani@ugm.ac.id) \\ ${ }^{2}$ Department of International Relations, Faculty of Social and Political Sciences; and \\ ASEAN Studies Center, Universitas Gadjah Mada
}

\begin{abstract}
This research focuses on the contribution of young millennials in reducing the risk of tidal flooding along the northern coast of Semarang. Young millennials have received special attention in disaster management, and the study of digital transformations in disaster management has become more significant. The objective of this study is to examine how smart disaster responses to natural disasters, specifically the case of tidal flooding in three districts of the city (North Semarang, Genuk, and Tugu) and a district nearby Demak Regency (Sayung). To obtain comprehensive results, this research uses qualitative methods, which data collected through in-depth interviews; Focus Groups Discussion (FGD); observations; and desk studies. This study finds that Millennials' involvement is very important due to their distance from political interests and innovatively able to offer strategies in reducing the problems caused by tidal floods. The involvement of millennials in disaster management is relevant, given that Semarang will soon enjoy the demographic bonus, i.e. have a significant percentage of its population of productive age. Lastly, this research argues that vibrant public participation in disaster management can only be possible under democratic circumstances. As the implication, the study on public active participation might help disaster risk reduction campaign.
\end{abstract}

\section{Keywords:}

millennials; disaster risk reduction; digital transformation; civil society role; Semarang

\section{Introduction}

It is undeniable that countries in various parts of the world, including countries in Southeast Asia, must deal with natural disasters such as earthquakes, volcanic eruptions, tsunamis, floods, tidal floods, hurricanes, landslides, drought, etc. Some natural disasters not only detrimentally affect the environment and ecosystem but also result in hundreds or thousands of deaths and the loss of billions and even trillions of US dollars. Take, for example, tsunami, Aceh, Indonesia (2004); tropical storms, Vietnam (2006); Cyclone Nargis,
Myanmar (2008); eruption of Mount Merapi, Indonesia (2010); the flooding in Bangkok, Thailand (2011); flooding in Muara District, Brunei Darussalam (2012); earthquakes in Negros and Cebu, Philippines (2012); Typhoon Haiyan, Philippines (2014); as well as recent tsunamis in Palu and Banten, Indonesia (2018). In 2011, the ASEAN Coordinating Centre for Humanitarian Assistance on Disaster Management (AHA Center) was established to provide rapid response and assistance to ASEAN Member States in disaster management and to build solidarity among ASEAN countries 
in disaster management. This center's founding cannot be separated from the events of the preceding decade, where ASEAN Member States often fell victim to natural disasters. Recognizing the significant risks faced, joint efforts to build disaster resilience are an important agenda for countries in ASEAN, as realized through "One ASEAN One Response". The ultimate goal is to ensure the ASEAN community is resilient to disasters and is able to build cooperation, collaboration, and solidarity between member states. The creation of the AHA Center as an ASEAN coordinating body for disaster management has enabled ASEAN member states to communicate and work as a community towards the shared goal of "One ASEAN One Response".

In 2016, Indonesia, through the National Disaster Management Agency (Badan Nasional Penanggulangan Bencana/BNPB), strengthened the AHA Center by sharing Indonesia's experience dealing with disasters. No less important is that, in the same year, The 28th ASEAN Community on Disaster Management (ACDM) meeting was held in Semarang City (Badan Nasional Penanggulangan Bencana, 2016). Semarang was chosen as the location of this important meeting because of the Central Java government's use of various best practices in dealing with various disasters. Data released by BNPB in 2016 states that Central Java has successfully dealt with several disasters, including the eruption of Mount Merapi (2010) and the Banjar Negara landslides (2014).

Semarang City, where experiences and lessons learned were shared at the 28th ACDM meeting, is interesting for further study, especially since there are still many other natural disasters that have not been properly resolved. For example, the Semarang City Government and related stakeholders are currently dealing with problems of tidal flooding. Tidal floods are events caused by sea level rise (Suhelmi, 2009) and involve the sea water reaching its highest point and extending over the land, in accordance with the elevation or morphology of the coastal land. Tidal floods have become major problems along the northern coast of Semarang City and Demak Regency, especially in North Semarang, Genuk, Tugu and Sayung Districts. Although flooding has drenched many settlements and disrupted the economic activities of the city, it remains a prime location for residents to live and develop their businesses, driven both by economic and historical factors. The continued use of these areas for settlements is among the factors contributing to the problem of flooding. It has also complicated the efforts of the Central Java Provincial Government and the Semarang City Government to minimize the impact of tidal flooding by relocating affected people. Many residents prefer living in areas that are vulnerable to flooding, for a variety of reasons, and ignore its impact.

Local residents often attempt to live with disaster without enough disaster management knowledge; as such, they cannot minimize the possibility of material or non-material losses. To accommodate such residents' choice to remain in areas affected by tidal flooding, disaster management efforts must be handled, not only by the government but also by local residents. Local people, especially youths, must become disaster management literate to improve their capacity for dealing with disasters at all levels of society. Youth involvement in improving disaster preparedness and building joint resilience is an important element that must receive serious attention from relevant stakeholders. This includes youths or millennials (Generation $Y$ ), who are characterized as smart, active, creative, innovative, revolutionary, and technology literate.

Trends in disaster management studies evolve over time. In the millennial era, disaster management studies have begun paying more attention to the role of civil society, recognizing the State's limited capacity to solve 
disaster problems. The active involvement of millennials is expected to have a positive effect on resolving the problem of tidal flooding, as on average they are not only superior in the field of science but also in the fields of technology and information. They are the generation that was born between 1980 and 2000 and grew up within a context of advanced technology; as such, members of this generation are now aged 18 to 38 . They are called millennials and theirs was the last generation born before the dawn of the new millennium.

Mannheim (1952) explains that individuals in a specific generation are persons born within a specific 20-year-span, and as such share similar social and historical dimensions. Within the context of Semarang City, in the next ten to twenty-five years, the millennials of Semarang City will face a demographic bonus, wherein residents of productive age will be far more in number than the elderly. According to data from the Semarang City Bureau of Statistics, in $2017,50 \%$ of persons of productive age are from the millennial generation; as such, it can be estimated that between 2030 and 2040, this number may reach $70 \%$. In other words, for the next ten to twenty-five years, the future of Semarang City will be more or less determined by its millennial population's intelligent response to the problem of tidal flooding and its contributions to overcoming the problem. This is important for further exploration, as these millennials will play an important role and help address the problem of tidal flooding in Semarang City. Based on our interviews with the village heads in northern Semarang, local government did not adequately involve the youngsters to be pro-active in reducing disaster risks. The village heads mention that the youth organizations, which are Karang Taruna in every village, were currently absorbed into sports and social routines.

To explore this problem, this research will focus on millennials' smart responses to tidal flooding along the northern coast of Java.
This study is highlighting four potentials that young millinials posses. First, maximizing the potential of the millennial generation, who are literate in information technology, willing to innovate, and have a capacity to quickly respond to disasters. Second, the fact that youth involvement as volunteers in disaster responses has increased from year to year. Third, the establishment of a coordination forum whose membership is dominated by youths. Forth, today's youths are the future leaders of the nation, and given that Semarang City will soon benefit from a demographic bonus their potential must be managed properly.

\section{Literature Review}

\section{Shifting Approach to Disaster Management}

Approaches to understanding disaster management shift from time to time. This study argues that there have been at least three major periods in disaster management approaches: first, the formulation of the concept of disaster management by first-world countries; second, the institutionalization of disaster management by the state; third, understanding of the relevance of civil society in handling disasters. At this time, it is not impossible for us to be heading towards a period in which civil society becomes increasingly important, given that the digital revolution has made people increasingly integrated through information technology. This study argues that disaster management must use the most up-to-date approach, combining actor inclusiveness and digital network-based activities.

Literature on disaster management argues that the formulation of the concept of disaster management was first initiated by developed countries involved in world wars (Quarantelli, 1995; Coppola, 2011). At the beginning of the 20th century, disaster management was unknown as a defense system. Based on their wartime experiences, developed countries' civil defense organizations began expanding the scope of their work to address disaster issues 
(Quarantelli, 1995). For instance, the United Kingdom's disaster management agency and the United States' Federal Management Agency (FEMA) were developed in the 1940s and 1950s to deal with natural disasters.

The second phase was marked by the institutionalization of disaster management in developing countries in the 1970s. Disaster management researchers argue that this was happening especially after the public saw that many developing countries did not have adequate mechanisms for dealing with natural disasters (Bildan, 2003; Sawada \& Zen, 2014). During this time, Indonesia followed the trend, establishing its national disaster management organization in 1979 (Bildan, 2003; Rum, 2016). What should be highlighted from these two initial phases is that all initiatives were begun by the state. Disaster management remained a predominantly state-run affair. Indeed, even today the public belief is that the state must be on the frontlines in dealing with disasters.

This approach has become less relevant at the dawn of the new millennium, when the world community realized the interconnectedness of human life. The world has not only witnessed major disasters across the world, but these disasters have proven to be beyond the managerial abilities of the state because of their large scale. In the earthquake in Marmara Turkey in 1999, the Indian Ocean earthquake and tsunami in 2004, and Cyclone Nargis in 2008, for example, civil society had to be involved due to the weak capacity of the State, which was plagued by other political and economic problems. Much of the literature produced in the new millennium has been oriented towards the inclusive handling of disasters involving various layers of society, as seen in the studies by late researchers (Adger et al., 2005; Aldrich, 2008; Patterson, 2010; Akeyo, 2010).

Adger and colleagues are of the view that resilience relies heavily on multilevel social networks. Learning from the case of the 2004 Aceh tsunami, where weak social capital resulted in higher vulnerability, Adger recommends that that the government not only allocate funds for technical approaches (i.e. controlling nature) but, more importantly, for building multilevel social networks that can support the development of regulation, political consolidation and social-ecological resilience (Adger et al., 2005). The nature of the social-ecological approach is to focus attention on natural interactions that are organic in the community itself. Government intervention alone does not necessarily result in a good exit strategy. Mechanisms that develop genuinely from within a community tend to result in more sustainable mechanisms for responding to disasters.

\section{Civil Society Support in Disaster Management}

A similar view was expressed by Patterson et al. (2010); in the contemporary era, disaster management is not the domain of the State, but rather civil society. Based on the experience of the United States in dealing with Hurricane Katrina in 2008, Patterson states that many scholars in this field have developed models of disaster management approaches that involve civil society. Smith and Wandel emphasize the role of civil society in identifying disaster risks and vulnerabilities. Basically, those who best understand the vulnerabilities and risks in their surroundings are the people who live in them. As such, they must be involved in the policymaking process (Patterson et al., 2010).

One such model, developed by Cutter and Emrich, is known as the Social Vulnerability Index (SOVI). In assessing the level of disaster vulnerability, one cannot forget the level of social capital within an area. The development of social contexts will vary between place and place. When Hurricane Katrina hit Bay St. Louis, for example, it struck a marginalized community with its own complex issues (limited economic access and social security) and thus a higher level of vulnerability. Even 
in the evacuation model, based on research conducted by Dash and Galdwin, the outcome of initial response patterns to disasters depends heavily on socio-economic factors, as well as individual experiences with previous disasters, knowledge, settlement characteristics, and information dissemination (Dash \& Galdwin 2005 as cited in Patterson et al., 2010).

Many policy recommendations neglect to recognize the importance of civil society support in disaster management. These neglected factors received attention by Aldrich, who noted that the Village de L'est in New Orleans was a community that recovered more rapidly after Hurricane Katrina in 2008 compared to other regions (given that government assistance was given evenly, but results showed different recovery levels), showing that the most important factor in the rapid recovery of business and citizen activities is the preparedness and active group of neighborhoods in the environment itself (Aldrich, 2008). It may be concluded, thus, that most of the contemporary disaster literature advocates the involvement of civil society as the most important component of disaster management.

In the context of Semarang, civil society involvement could be very influential. Due to their limited access to money and power, the poor people living in coastal Semarang have been forced to endure tidal floods and slowly adapt to this situation (Wahyuni, Fitrah, Handayani, \& Robie, 2018). These marginalized people should be empowered to have a fair share in helping tackle natural disasters.

\section{Youth, Information Technology Transformation and Public Relations in Disaster Management}

The literature that has developed over the past four years has shown an expansion to involve civil society through the internet. The development of the digital industry has influenced social relations and eased the integration of early warning systems, information dissemination, and evacuation models into a disaster management regime. de Albuquerque, Herfort, Brenning \& Zipf (2015) examining the use of social media and official data from government agencies, concluded that these can contribute positively to disaster management. Albuquerque and his team's dataset provided useful information for disaster management in Magdeburg, Halle, Berlin, and several important areas such as Munich and the Ruhr area of Germany (de Albuquerque et al., 2015).

Likewise, research by Houston et al. (2014) on social media activism in response to Tornado Joplin in Missouri in 2011 showed that individuals, both those who were affected by the tornado and those who were not, were able to develop a hub, an information site that served as a center for disseminating information, assisting coordination, and mobilizing volunteers (Houston et al., 2014). These studies show that it is important for us to integrate an approach that involves civil society with the development of the digital industry.

On the role of the youth in disaster management, Mitchell et al. (2008) and Akeyo (2010) offer relevant insights. Mitchell et al. argues that in most of the cases, children and youth are excluded from the process of establishing a resilient disaster management due to top-down approach being the dominant mechanism in policy making (Mitchel et al., 2008). Mitchell et al. proposes that we should not forget that in the near future, these young people will lead the society; hence, encouraging their participation in disaster management today means ensuring the ownership of a resilient society tomorrow (Mitchel et al. 2008, p. 257). Meanwhile, Akeyo suggests that any disaster management initiative involving the youth might get benefits of creativity and energetic commitments emanated from fresh and highly motivated younger people (Akeyo, 2010). Hence, we argue that the youth should 
be incorporated within disaster mitigation, preparedness and response plan.

What is lacking from the studies mentioned above is a discussion of the political aspects of digital transformation. Therefore, this research positions itself as a political study of digitizing disaster management, one aimed at combining an inclusive approach of disaster management with the need for civil society to carry out digital transformations in dealing with disasters, thereby promoting a redefinition of government and community relations. In this article, focus is given to millennials, a younger generation connected with the development of technology and information. In addition, the demographic bonus that Indonesia is expected to experience in the next 30 years also makes this group a significant part of Indonesian society. This group is also familiar with the key concepts of social media and digital transformation.

\section{Methods}

To get comprehensive results, this study used a qualitative research method with a case study approach and collected data through several methods: first, in-depth interviews with local residents of North Semarang, Genuk, Tugu, and Sayung as well as members of four civil society organizations, namely: (a) Coastal Lanterns (Lentera Pesisir), (b) Mangrove Ecosystem Study Group Teluk Awur (Kelompok Studi Ekosistem Mangrove Teluk Awur/ KeSEMAT), (c) KeSEMaT Alumni Association (Ikatan Alumni KeSEMaT/IKAMaT), and (d) Barcode. The authors met with the key informants and explored more information based on their experience as actors involved in solving the problem of tidal flooding. Second, Focus Group Discussions (FGDs) were conducted with (a) Center for Coastal Rehabilitation and Disaster Mitigation Studies (CoREM) of Diponegoro University, (b) Central Java Development Planning Board and Semarang Development Planning Board, (c)
Central Java Provincial Disaster Management Office, (d) heads of North Semarang, Genuk, Tugu, and Sayung districts, Demak Regency. This approach was chosen to collect data information more deeply with those problems that occur based on various key informant and different perspective. Third, field research observations in several districts of Semarang City (North Semarang, Genuk, Tugu) as well as Sayung District in Demak Regency. With the observation approach, the authors can collect data in the field and have a chance to meet and ask with local people who affected with tidal flooding and know more the situation. Forth, extracting secondary data from relevant government documents, books, journals, academic studies, and mass media articles. This approach is very helpful for the authors to clarify, explore, and analyze more data before and after doing research in the field.

The study was conducted over a period of five months, from April to August 2018. After finish collecting data, the authors validated the data and source with triangulation. Triangulation is a way to validate data and information obtained by the authors from various perspective and various background of the key informants. So, the research result can be approached from the point of view because the authors are not portrayed from a single phenomenon to analyze the problem of tidal flooding in three districts of the city (North Semarang, Genuk, and Tugu) and a district nearby Demak Regency (Sayung). Moreover, for data analysis technique, the authors use interactive model by Miles and Huberman (1992). With this technique, the authors analyzed by data reduction, data display, and conclusion drawing/ verification. Data reduction was done during the research activity for focusing the author's attention to collect the main data. Furthermore, in presenting data, the authors has analyzed the data and information that has been obtained and then presented. After that, for conclusion drawing/verification 
is done to review the research findings that have been presented. Draw conclusions from the research result still need to be verified so the research results can be accounted for.

\section{Results and Discussion \\ Millennials Time to Contribute: Smart Disaster Response}

The problem of frequent tidal flooding along the northern coast of Java has yet to be resolved, despite various efforts conducted by the Government in conjunction with stakeholders. Projects such as building integrated sea water barriers (on land and at sea), river normalization, pumping, making retention ponds, sea dike construction, road elevation, etc. have unfortunately been unable to resolve the problem. Almost every day, especially during the rainy season, tens or hundreds of houses in northern Semarang City are affected by tidal floods. The waters may not only seep onto residents' floors; they may reach depths of more than two meters, leaving the houses inundated and uninhabitable. When the research team conducted observations in North Semarang, Genuk, Tugu, and Sayung, they witnessed firsthand the conditions of these settlements and the lives of local residents. Even when houses are flooded or submerged in seawater, they must continue to work to ensure that their daily needs are met.

Every time that there are signs of rising seawater, residents must be prepared to move their household furniture to a higher place so that the items are not damaged. Residents feel their mobility is limited, as they have no dry place available for such activities as cooking and resting. Inevitably, they must conduct their daily activities in pools of rancid black water. Unfortunately, despite their situation, residents are reluctant to evacuate. They remain at home, seeking to maintain their assets and seemingly not caring about their health. Not infrequently, people in the area are afflicted by skin disease and even dengue fever.
Local residents have tried to adapt to these conditions for decades. Two prominent methods have been used: (1) those with the economic capacity will attempt to elevate their homes every few years to ensure that they are protected from flooding; and (2) those without sufficient economic capacity will endure, even though their homes are lower than average (generally only 1.5 to 1.75 meters from the ground). Residents who can no longer inhabit their homes have no other choice but to move to another area. See, as an example, Picture 1.

\section{Picture 1.}

\section{Houses Submerged by Tidal Flood in} Terboyo Kulon

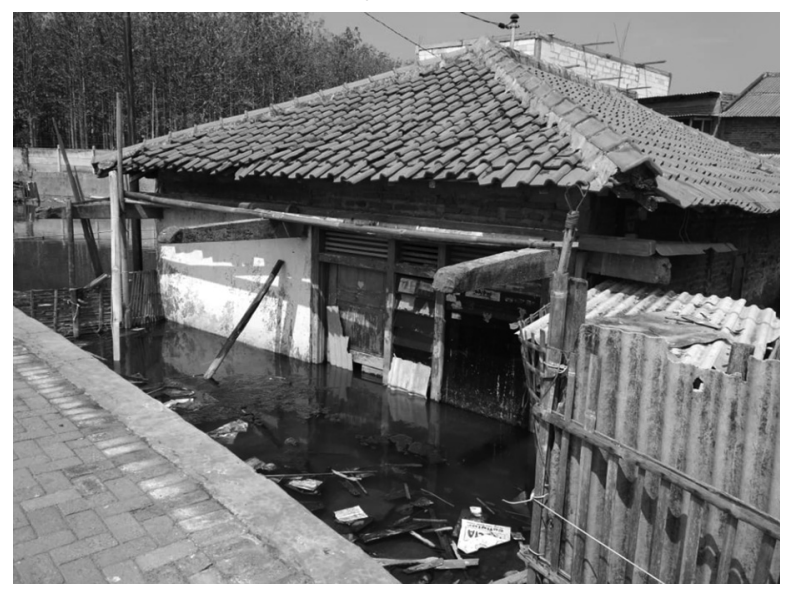

Source: Researcher's documentation, August 2, 2018

Seeing events like this every day has driven the young people of Semarang to become agents of change. They have taken an energetic, smart, innovative, and creative role in their communities. Researchers met with members of several youth communities, including Lentera Pesisir, KeSEMAT, IKAMaT, and Barcode, which have promoted innovative ideas and out-of-the-box thinking. They have used many approaches to encourage transformations in their problem-solving approaches. These groups will be profiled below.

First, Lentera Pesisir, a volunteer organization founded by three young alumni 
of Diponegoro University in 2017. Since its founding, this organization has grown to include more than 80 volunteers, all young students from various academic disciplines and from various private and state universities in Semarang. Local residents have enthusiastically accepted this organization because (1) Lentera Pesisir is able to educate local residents about the importance of protecting coastal ecosystems by providing classes every Saturday and Sunday from 8 to 10 a.m. Volunteers invite the children of local residents, generally elementary school students, to invite them to learn about the coastal environment and ecosystem. These lessons are delivered simply but easily understood by children, with approaches including playing games, reading books, watching movies, reading poetry, or telling stories. Such an approach to learning is paramount in preparing future generations to understand their environment, including the rampant tidal flooding. Interestingly, these joint learning activities are conducted near where children live, usually at the "Floating House" (rumah apung) built by the Semarang City Government. Built in a flooded area, it is the only floating house in Semarang City.

(2) Lentera Pesisir also conducts various community empowerment activities, such as by teaching local residents how to process shellfish products into souvenirs such as headbands, lamp ornaments, glass ornaments, etc. (3) Lentera Pesisir invites local residents, especially mothers, to process shrimp into shrimp paste. This production not only provides them with economic benefits but also empowers local women's groups. (4) Lentera Pesisir urges local residents not to cut down the mangrove trees planted on the coast. (5) Lentera Pesisir works together with cross-community volunteers who are concerned with coastal environmental ecosystems. This has included the World CleanUp Day activity, held on September 15-16, 2018, to increase environmental awareness. A similar activity was conducted the previous year.
As a volunteer organization, Lentera Pesisir has provided examples of real contributions with a positive influence on local communities, especially in Tambak Lorok. These activities have enabled young people to become important agents of change. Although they conduct their activities on a volunteer basis, rather than for material reward, they have a strong passion for challenging the problem of tidal flooding in the area. Moreover, with their digital literacy, these young volunteers also make use of technological and information advancements to disseminate their activities through websites and social media, not only for documentation but also to attract the interest of other communities and potential volunteers.

Second, KeSEMaT. KeSEMaT is a student organization under the Department of Marine Sciences, Faculty of Fisheries and Marine Sciences, Diponegoro University, which is engaged in mangrove and coastal ecosystem conservation. Established in 2001, its mission and objective are to develop students' research on mangrove ecosystems, foster and enhance a love of mangroves among members, students and general society, and developing and realizing scientific activities that promote mangrove conservation. Its motto is "Conservation, research, campaign, education, and documentation of mangroves for future generations."

To realize its mission and goals, KeSEMaT also has a unique learning concept, an internetbased mangrove campaign program called KeSEMaTONLINE Network. Located at kesemat.or.id, this network has eased mangrove campaigning in Indonesia.

Another creative idea in KeSEMaT's disaster response is its visualization of the tidal flood conditions that are a daily sight in Semarang City through a short documentary film. Initiated by Sapto Pamungkas (IKAMaT) and Fuad Ashari (KeSEMaTER), this film is titled Kampung Rob di Jantung Kota (Tidal Flood Villages in the Heart of the City). It follows the struggles of a father, Supardi Warno, who seeks 
to adapt, overcome, and utilize the tidal floods in Semarang. One of the residents of a coastal settlement in Semarang, Supardi invited his neighbors to adapt to the condition of rising sea levels and land subsidence. Mangrove deforestation, as a result of logging, has occurred since the colonial area; by the time the documentary was made, more than $90 \%$ of the area's mangrove trees had been harvested. However, these conditions did not discourage Supardi, who exploited the tidal flooding to benefit his community. This story idea is very interesting, and it managed to draw critical attention. It was one of five finalists in the 2012 Eagle Awards Documentary Competition (EADC), held by Metro TV, having beaten out hundreds of other short films.

Other creative breakthroughs by millennials was the establishment of KeSEMaT Mangrove Volunteer (KeMANGTEER) in various coastal cities in Indonesia. KeSEMat has more of a dozen of administered initiatives. First, they administer a mangrove-related portal called KeSEMaTONLINE. Second, the publication of mangrove books. Third, the establishment of mangrove mapping services through Mangrove Map. Forth, the direction of mangrove films. Fifth, the writing of mangrove stories through Cerita Mangrove Cermang. Sixth, the publication of a mangrove magazine through MANGROVEMAGZ. Seventh, the making of Mangrove batik; eighth, the initiation of a Mangrove Dolls program through Boneka Mangrove/Bomang. Ninth, the drawing of mangrove comics through Mangrove Mat Kesem Detective. Tenth, the initiation of the child mangrover program through Mangrover Cilik/Mangcil. Eleventh, the creation of a mangrove band through KeSEMaTUSTIK. Twelfth, the founding of a Coins for Mangroves movement. Last but not least, they are active in campaigning on social media/networks, including YouTube, Google+, Facebook, Twitter, Instagram, Blog, etc. This suggests that KeSEMaT is very innovative in its mangrove campaigning, being modern but not abandoning the conventional.

In its community empowerment activities, KeSEMaT has also assisted villages and smalland-medium business groups (MSMEs) to improve the financial capacity of coastal residents. These have included: (1) mangrove batik groups; (2) mangrove product groups (making raw mangrove crackers, mangrove sticks, etc.); (3) mangrove souvenir groups (making pins, mugs, stickers, hats, key chains, calendars, t-shirts, etc.). The organization even have a Semarang Mangrove Center, which it uses to sell these groups' products. In the realm of tourism, the organization has also succeeded in promoting the establishment of the Mangrove Botanical Gardens-MECoK Ecopark -in Jepara, Central Java.

Not surprisingly, these student organizations have received a number of prestigious awards both at home and abroad, including: (1) Award of the Chancellor of the Diponegoro University (2011); (2) First Place in the National CAMPUS COMPASS Green Living and Youth Creativity Award (2012); (3) Coastal Award Winner, Academics Category, from the Ministry of Maritime Affairs and Fisheries of the Republic of Indonesia (2012); (4) KEHATI Award VIII (2015); (5) Soegondo Djojopoespito Award, from the Ministry of Youth and Sports of the Republic of Indonesia (2015); (6) ASEAN Accorded Youth Organization in ASEAN (TAYO) Award from the Ministry of Education, Youth, and Sports of Cambodia and the ASEAN Secretariat (2016), (7) 1st Place, Nature Lovers Group, Central Java (2017); and (8) Wana Lestari Award for Nature Lovers Group, from the Ministry of Environment and Forestry of the Republic of Indonesia (2017).

Another interesting phenomenon is that, even after graduation from the Department of Marine Sciences, KeSEMaT members remain active with the organization. Through IKAMaT, alumni can maintain good relations with KeSEMaT, who are the responsibility 
of the campus. IKAMaT is a forum for KeSEMaT alumni that was formed with the aim of organizing empowerment and coaching activities, for improving the quality of life of coastal communities, forging cooperation with various governmental and non-governmental agencies, and promoting the conservation of mangrove ecosystems and the empowerment of coastal communities.

In the field of education, IKAMaT is also committed to assisting coastal children in Indonesia through the Indonesian Coastal Children Scholarship program. IKAMaT distributes donations, in the form of scholarships, as a means to develop students' passion for conserving mangrove ecosystems. These donations are collected through KeSEMaT's Coins for Mangroves movement, a fundraising activity that is intended to protect mangrove ecosystems and coastal communities, not only in Semarang or Central Java but also in other parts of Indonesia and around the world.

Fourth is Barcode, a student community from the Department of Computer Science, Diponegoro University, which consists of young people with smart ideas for creating start-up applications. Recognizing their expertise, CoREM has invited Barcode to help visualize the tidal flooding in the form of a digital calendar. This calendar, known as Rob Calendar-rob being an Indonesian word for tidal flooding - can be downloaded via the Play Store for free. Picture 2 shows a screenshot of the Rob Calendar application.

This application provides data on water levels at specific times. It is hoped that in the future, this application will not only be presented in Indonesian but also in English, thereby enabling it to reach the broader community.

Learning from these four communities, the Research Team has reached the tentative conclusion that millennials who are members of such communities have demonstrated their ability to utilize information technology. Born

Picture 2.

The Interface of the Rob Calendar Application
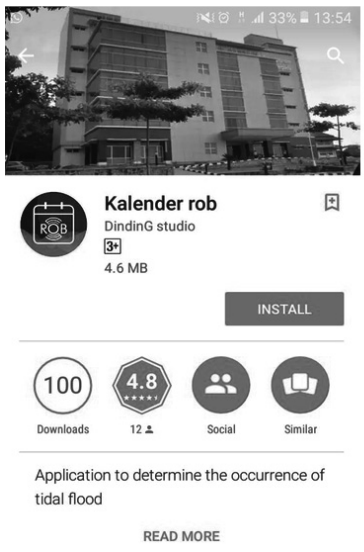

Source: Play Store application

and raised in the millennial era, they have not only witnessed the development of information technology but also become active and eloquent subjects in its use. The dissemination of information about their activities is rapid and has positively affected Semarang City, which is often afflicted by floods.

\section{Smart Interactions with Regional Heads through Social Media}

Youth are no longer positioned as vulnerable groups or victims, but rather as individuals who are ready to be at the forefront of disaster management. Many young people have been called to become volunteer disaster responders by going directly to help victims of disaster in various parts of Indonesia. This is in-line with the statement of Anderson (2005) as cited in Fothergill (2017), who states that:

"Children are not just passive victims or dependent observers, and ... the actions that they take beg for documentation, which the field has begun. It has become clear, at the same time, that children and youth are vulnerable, they also demonstrate important and often unnoticed capabilities and strengths, as they assist themselves and others before and after a disaster strikes." 
This statement indicates that youths are an important element of society that must be involved in disaster management, especially in building public awareness of the importance of disaster knowledge. The role of youths, with their intellectual abilities, can have a positive effect on the formation of disaster resilient communities. This cannot be separated from their characterization as strong, innovative, creative, and productive. Youths can be society's main instrument to strengthen community capacity in reducing disaster risks and vulnerabilities.

The same thing is also mentioned by Margareta Wahlström (the former special representative of the UN Secretary-General for Disaster Risk Reduction) on the official website of the United Nations Office for Disaster Risk Reduction (UNISDR), 2015, which states:

"One of the easiest disaster risk reduction measures we can take is to empower children and youth and ensure they are actively involved in disaster risk reduction and contribute to making their cities and communities resilient to disasters. Denying them this right would be denying them from influencing their own future."

If we trace developments over the past ten years, the central and regional governments of Indonesia have also voiced various kinds of declarations on youth disaster response volunteers and held various disaster response training activities that target young people in almost all parts of the country. This is an important factor because, geographically, Indonesia is at risk of numerous natural disasters and often hit by multiple disasters in a short period of time. With the involvement of youth, they can not only help alleviate the effects of natural disasters but also become pioneers of disaster preparedness with the capacity, capability, and experience to help others handle disasters (Ministry of Youth and Sports of the Republic of Indonesia, 2011; Wulandari, 2015).

Moreover, the disaster preparedness training received by the youth can be socialized and shared with other millennial generation. As such, they can increase youths' enthusiasm and concern to be directly involved in disaster management. In addition, as they live side by side with disaster, they must also develop a spirit of "victims helping victims" when a disaster occurs, meaning that survivors of disasters must help other victims (Andriyanto, 2011, p. 48). For this reason, youths must have the ability to move quickly in the face of disaster and learn about potential disaster risks in their region. In addition, youths should also develop their networks through various communities and coordination forums whose membership base is dominated by young people interested in disaster issues.

After observing and conducting interviews, the Research Team also tried to establish interactions with regional leaders. We utilized social media, including Twitter; we chose to use Twitter because many regional heads, including governors, mayors, and regents use social media. This includes Ganjar Pranowo, the governor of Central Java. We sought to establish discussions with him and sent a message to Ganjar Pranowo's Twitter account, as follows (text message in Indonesian).

We sent this message after interviewing local residents, especially those who lived in Sriwulan Village, Sayung District. We tried to convey what Pranowo had promised to residents when he visited the village. This message, translated to English, reads:

“@ganjarpranowo Good afternoon, Mr. Governor. I would like to report that I have gone to Sri Wulan Village in Sayung District, Demak Regency. Residents of RT 06/RW 01 complained a lot about the tidal floods, which are very bad. Last year, during Eid, you promised to go on the road, but that hasn't been realized yet." 


\section{Picture 3.}

Screenshot of a text message on Twitter

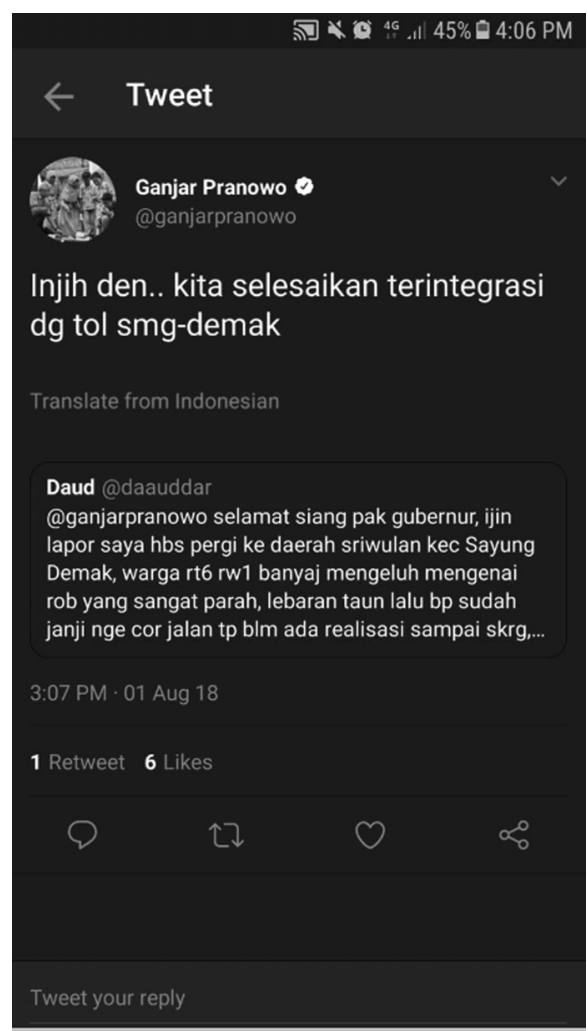

Source: Researcher documentation, August 1, 2018

The message received a rapid response from Pranowo, who replied as follows (translated into English):

“@daauddar Yes Sir, we (will) complete it integrated with the Semarang - Demak toll road"

The message that we sent was intended to inform the regional leader of the real conditions we found on the ground during the research, as well as a means for regional leader to respond to citizens' aspirations. The screenshot above is concrete proof that regional leaders respond by replying to incoming mentions. Attempts to stay close to the people and be open to communication are, of course, able to establish interaction, but what is most expected is the immediate resolution of the problem. As such, the social media response should not be seen as a strategy for portraying Pranowo as a responsive leader but as a problem solver.

\section{The Demographic Bonus as a Motor of Future Development}

The demographic bonus is a phenomenon wherein the percentage of a population of productive age (i.e. between 15 and 64 years of age) is greater than the percentage of a population of non-productive age. This is evident in Semarang City, where persons of productive age represent more than half of the total population. With so many people of productive age, proper management of the population will enable maximal benefits. As such, the demographic bonus that is predicted to occur in the next ten to twenty-five years can offer a golden opportunity for Semarang City to engage its citizens while appreciating those who are able to contribute positively to resolving problems such as tidal flooding.

Demographic bonus studies are currently being conducted by almost all of Indonesia's local governments, including in Semarang City. The demographic bonus that is expected to occur in 2030-2040 must receive preparation because the number of people of productive age will be double the number of those categorized as non-productive. This demographic bonus will benefit Semarang City if the local government is able to direct people to become actively involved in various activities, including environmental and disaster mitigation activities.

The demographic bonus may be a motor of development for Semarang City, especially if the local government and related stakeholders can provide space for millennials to help solve problems. The results of the study proved that these four communities have been serious in dealing with tidal flooding and coastal ecosystems. These four communities have been able to maximize their involvement in various activities. They are an example of educated youths who have strategically become part of the development and growth of their communities. In other words, these four communities - as well as other communities 
with environmental sensitivity - can play an important role in disaster mitigation. With their knowledge and capacity, they can produce useful ideas for the future of Semarang. In addition, their involvement is relatively free of political interests, and as such these youths can use various smart and innovative strategies to solve the problem of tidal flooding.

This paper reinforces the view that wider public participation is important to set a foundation for better disaster management. We found that the vibrant youth participation in Semarang has only been possible because the political condition allows it. To some extent, democratization in Indonesia has helped youth organizations actively deal with social problems. As such, better disaster management is closely related to democracy level. This supports previous studies on the politics of disaster, which have shown a strong connection between politics and responses to disasters (Drury, Olson \& Van Belle, 2005; Olasky, 2006; Lakoff, 2010; Pelling \& Dill, 2010). Scholars have examined the interconnection between social structuration and societies' ability at different levels to respond to disasters. Vulnerability is not only determined by inherent qualities of society itself but also shaped by socio-political structures. Although the government remains important in managing and initiating disaster response, growing concern over the scale of disaster has influenced new ideas to invite the involvement of wider actors.

In terms of the sustainability of civil society initiatives in disaster risk reduction, this study found promising developments. Organizations like KeSEMAT, IKAMaT, and Lentera Pesisir continues to recruit new volunteers. Dozens of new members are registered in each period of initiation annually. It has been 18 years for KeSEMAT to work in planting mangroves since 2001. Lentera Pesisir has been working for about two years from 2017 to 2019 in educating coastal children. The activities they are doing at the moment in
Semarang are taught to new members. New volunteers are coming from various regions. They share knowledge so that what is done in Semarang can be sustained and can inspire activities in other areas.

\section{Conclusion}

This paper reinvigorates the proposition that wider public participation is important to set the foundation of better disaster management. We found that vibrant youth participation in Semarang could only be possible when political condition allows it. In some extent, democratization in Indonesia has helped youth organizations to be active in dealing with social problems. Hence, better disaster management is closely related to democratization level. It further strengthens previous works of literature on the politics of disaster, showing a strong connection between responses to disaster and politics. Scholars have examined the interconnection between social structuration and societies' ability at different levels to respond to disasters. Vulnerability is not only determined by inherent qualities of society itself but also shaped by socio-political structures. Although the government remains important in managing and initiating disaster response, growing concern over the scale of disaster has influenced new ideas to invite wider actors' involvement.

Even though in a democratic environment, cases of postponement of political promises still happen due to technical problems, elected leader is willing to communicate with the people, as demonstrated by Governor Pranowo's promise to the people of Sriwulan. In recent years, there has been greater public participation in disaster risk mitigation with the involvement of youth organizations such as KeSEMAT, IKAMaT, Barcode, and Lentera Pesisir. As argued by Amartya Sen in his magnum opus, Development as Freedom (1999), a society with a more vibrant democracy is more likely to weather a catastrophic crisis 
than one under a dictatorship. Civil society and media in democratic countries can better collect necessary information and disseminate warnings or important notices. Meanwhile, censorship and centralized information dissemination hinder the government's ability to collect data from the field. As such, a lack of media freedom would affect risk and societal vulnerability. The involvement of IKAMaT, KeSEMAT, Barcode, and Lentera Pesisir in Semarang offers a promising future for disaster management in democratized Indonesia.

Semarang case can be a valuable lesson for many places that are vulnerable to disasters. What young people do in Semarang is a remarkable social capital that will help the government and society to react accordingly when disaster strikes. Awareness and social actions that are formed genuinely from the people will be able to sustain better than initiatives that are merely top-down from the government alone. At the national level, we need to create an environment that supports the growth of genuine civil society initiatives in disaster management, especially in post-disaster recovery period such as in Lombok, Palu and Donggala, and also Banten. At the global level, people empowerment and bottom up disaster risk reduction approach can help developing countries, considering their limited economic capacity, to better respond to disasters.

\section{Acknowledgments}

The researchers would like to express their appreciation to the Research Directorate of Universitas Gadjah Mada, which supported and funded this research through the "Capacity Building for Young Lecturers Grant" through the 2018 budget. Furthermore, the researchers would like to express their gratitude to their colleagues at the Department of Politics and Government and the Department of International Relations, Faculty of Social and Political Sciences, Universitas Gadjah Mada, who entrusted us with the opportunity to conduct this research. We would also like to thank Dr. Wawan Mas'udi of Universitas Gadjah Mada for supervising our research, Prof. Shimada Yuzuru of Nagoya University for his feedback, as well as to Muhammad Ilham Imanuddin and Daud Arie Ristiyono for their assistance during field research. The researchers would also like to thank the Center for Southeast Asian Social Studies (CESASS), Universitas Gadjah Mada, especially Dr.phil. Hermin Indah Wahyuni and Andi Awaludin Fitrah; and the Center for Coastal Rehabilitation and Disaster Mitigation Studies (CoREM) of Diponegoro University, Semarang, which always supported them in this multidisciplinary collaborative research. The previous version of this paper was presented at the 2018 Wenzao International Conference on Southeast Asia Studies (2018 Wenzao ICSEAS), October 25-27, 2018, in Kaohsiung, Taiwan, but never published.

\section{References}

Adger, W. N., Hughes, T. P., Folke, C., Carpenter, S. R., \& Rockström, J. (2005). Social-ecological resilience to coastal disasters. Science, 309(5737), 1036-1039. doi: $10.1126 /$ science. 1112122

Akeyo, S. O. (2010). Youth involvement in disaster management. Paper presented at The 5th Annual Caribbean Conference on Comprehensive Disaster Management in Jamaica, Montego Bay.

Aldrich, D. P. (2008). The crucial role of civil society in disaster recovery and Japan's preparedness for emergencies. Japan Aktuell, 3, 81-96.

Andriyanto, W. (2011). Aksi pemuda: Panduan Pengurangan Risiko Bencana berbasis Komunitas (PRBBK) untuk pemuda. Jakarta: Deputi Bidang Pemberdayaan Pemuda, Kementerian Pemuda dan Olahraga, Republik Indonesia.

Badan Nasional Penanggulangan Bencana. (2016). Membangun satu masyarakat ASEAN yang lebih tangguh. Retrieved 
from https://www.bnpb.go.id/index.php/ membangun-satu-masyarakat-aseanyang-lebih-tangguh

Bildan, L. (2003). Disaster management in Southeast Asia: An overview. Bangkok: Asian Disaster Preparedness Center.

Coppola, D. P. (2011). Introduction to international disaster management (2nd ed.). Burlington: Elsevier.

de Albuquerque, J. P., Herfort, B., Brenning, A., \& Zipf, A. (2015). A geographic approach for combining social media and authoritative data towards identifying useful information for disaster management. International Journal of Geographical Information Science, 29(4), 667689. doi: 10.1080/13658816.2014.996567

Drury, A. O., Olson, R. S., \& van Belle, D. A. (2005). The politics of humanitarian aid: US foreign disaster assistance 1964-1995. The Journal of Politics, 67(2), 454-473. doi: 10.1111/j.1468-2508.2005.00324.x

Fothergill, A. (Ed.). (2017). Children, youth, and disaster. Oxford Research Encyclopedia of Natural Hazard Science. Retrieved from http://naturalhazardscience. oxfordre.com/view/10.1093/ acrefore/9780199389407.001.0001/ acrefore-9780199389407-e-23 doi: 10.1093/ acrefore/9780199389407.013.23

Houston, J. B., Hawthorne, J., Perreault, M. F., Park, E. H., Goldstein, H. M., Halliwell, M. R., ...., Griffth, S. A. (2014). Social media and disasters: A functional framework for social media use in disaster planning, response, and research. Disasters, 39(1), 1-22. doi: 10.1111/disa.12092

Lakoff, A. (2010). Disaster and politics of intervention. New York: Columbia University Press.

Mannheim, K. (1952). The problem of generations. In P. Kecskemeti (Ed.), Essays on the Sociology of Knowledge (pp. 276-320). London: Routledge and Kegan Paul.
Miles, M. B., \& Huberman, A. M. (1992). Analisis data kualitatif buku sumber tentang metode-metode baru. Jakarta: Universitas Indonesia Press.

Mitchell, T., Haynes, K., Hall, N., Choong, W., \& Oven, K. (2008). The roles of children and youth in communicating disaster risk. Children, Youth and Environments, 18(1), 254-279.

Olasky, M. (2006). The politics of disaster: Katrina, big government, and a new strategy for future crises. Nashville: W Publishing Group.

Patterson, O., Weil, F., \& Patel, K. (2010). The role of community in disaster response: Conceptual models. Population Research and Policy Review, 29(2), 127-141. doi: 10.1007/s11113-009-9133-x

Pelling, M., \& Dill, K. (2010). Disaster politics: Tipping points for change in the adaptation of sociopolitical regimes. Progress in Human Geography, 34(1), 21-37. doi: 10.1177/0309132509105004

Quarantelli, E. L. (1995). Disaster planning, emergency management, and civil protection: The historical development and current characteristics of organized efforts to prevent and respond to disaster. Newark: University of Delaware Disaster Research Center.

Rum, M. (2016). The case of regional disaster management cooperation in ASEAN: A constructivist approach to understanding how international norms travel. Southeast Asian Studies, 5(3), 491-514. doi: 10.20495/ seas.5.3_491

Sawada, Y., \& Zen, F. (2014). Disaster management in ASEAN. ERIA Discussion Paper Series, 1-48.

Sen, A. (1999). Development as freedom. New York: Knopf.

Kementerian Pemuda dan Olahraga Republik Indonesia/Kemenpora. (2011). Pelatihan pemuda siaga bencana. Retrieved from http://www.kemenpora.go.id/index/ preview/berita/4082. 
Suhelmi, I. R. (2009). Pemanfaatan Multimedia dalam visualisasi model rob berbasis ssistem informasi geografi di Semarang. Jurnal Kebencanaan Indonesia, 2(2), 25-31.

Wahyuni, H.I., Fitrah, A.A., Handayani, F., \& Robie, D. (2018). Ecological communication in Asia-Pacific: A comparative analysis of social adaptation to maritime disaster in Indonesia and Fiji. Pacific Journalism Review, 24(1), 12-36. doi: 10.24135/pjr.v24i1.390
Wulandari, I. (2015, November 23). Kemenpora tantang pemuda menjadi relawan tanggap bencana. Republika.co.id. Retrieved from http://www.republika. co.id/berita/nasional/umum/15/11/23/ ny9ofu346-kemenpora-tantang-pemudamenjadi-relawan-tanggap-bencana.

United Nations Office for Disaster Risk Reduction (UNISDR). (2015). Child-friendly Sendai Framework. Retrieved from https://www. unisdr.org/partners/children-youth 